\title{
Kenmerke van 'n kerkorde van betekenis vir 'n geloofsgemeenskap in 'n postmoderne konteks, met spesifieke verwysing na die werk van Zygmunt Bauman

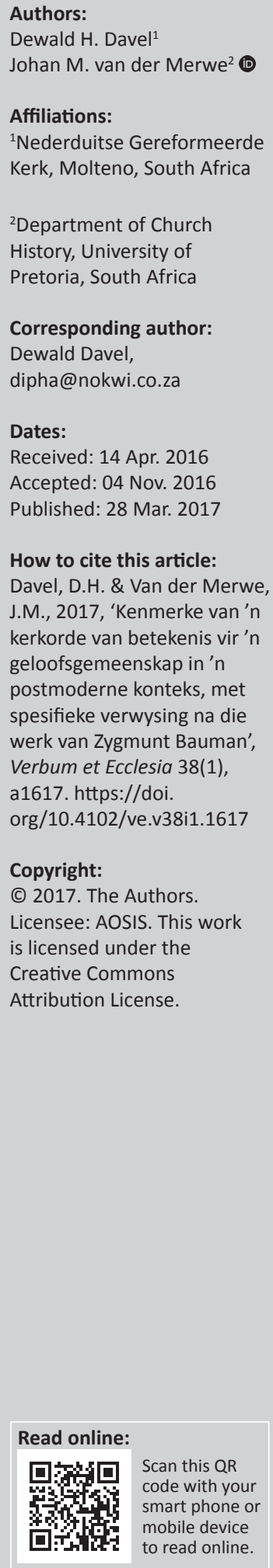

Characteristics of church ordinances with meaning for faith communities in a postmodern context, with spesific reference to the work of Zygmunt Bauman. Postmodernity changed the function, content and structures of church ordinances. This is a reality that cannot be denied by faith communities. New possibilities arise. Every 'absolute truth' can be formulated in a different way. Multiple truths suggest multiple possibilities. Plurality does not create chaos and risks anymore, but implies richness. Success and achievement have become relative to relations and the meaning of relationships. Individuals and small groups have discovered their own worth and identity. The disgust for rules has become the energy for the venture into new meaning. According to Bauman, the choice for humanity, including the church, is between ethics and morality. The individual's responsibility to every Other is clear. Respect for diversity is the challenge. A new search for identity and meaning, as found in relationships is what characterises our time. Rules will not be of any help; the understanding of every Other's story is important. The concepts to take into consideration are meaning, integrity, relativity, diversity, communication, justice and identity. A church ordinance of meaning should have the following characteristics: room for experimentation, complementary straights, room for people to be heard, authority carried by truth, a liturgical character, minimum geographical limits, room for diversity, structures that serve and an open view on offices.

Intradisciplinary and/or interdisciplinary implications: The study identify new arguments in the debate regarding the formulation and implimentation of a church-order. In the current context of postmodernity, where power and instruments of power are challenged, the debate regarding church polity finds itself at a critical point. The study suggests that the current definitions and models of church-orders are not beneficial to the church regarding her mission in the world anymore. The researcher is of the opinion that the changes suggested, are possible and needed. The academic discipline of church polity will have to take note of these, in order to stay relevant in a postmodern context. In formulating the arguments, the researcher made use of sosiological perspectives.

The function of rules is to give us the false feeling that, when we have complied in a minimal way, we can turn around. Rules are a mechanism for switching off our moral capacity, not a means of activating or fulfilling it. (Smith 1999:164)

\section{Probleemstelling, werkswyse en hipotese}

Koffeman (2009:37-42; 2014:31-34) verwys na Dombois se drieledige onderskeid in die ontwikkeling van die kerkreg en dui aan dat selfs wat die kerkreg betref, verandering 'n gegewe is. Koffeman (2009) gebruik die konsepte, ekumenies en missionaal, om die huidige veranderinge te beskryf.

Die navorser is van mening dat dié fase van ekumenisiteit aan die afspeel is binne 'n konteks van postmoderniteit. Dié twee, ekumenisiteit en postmoderniteit, is in wisselwerking met mekaar. In die era van moderniteit het oortuigings en identiteit duidelike vakkies gehad in die vorm van denominasies. Op grond van die verskille het die denominasies hulle van mekaar onderskei. Met postmoderniteit word die verskille gerelativeer ter wille van verhoudinge. Die verskille, soos later sal blyk, word nie meer beskou as onkruid nie, maar dalk eerder as kruie wat bydra tot die rykdom van smake. Hoe meer die blootstelling aan die verskille, hoe meer die aanvaarding daarvan. Hoe meer die aanvaarding, hoe meer die soeke na die betekenis van die verskille. Waarheen die proses op pad is, is glad nie duidelik nie. Wat wel duidelik is, is dat relatiwiteit in 'n baie groter mate deel van die mens se denkraamwerk geword het. 
Individue is besig om in ' $n$ toenemende mate hulle keuses, verbintenisse en gedrag te heroorweeg in terme van die waarde wat elkeen vir hulle inhou. Deel van die berekening is ook die prys wat dit van hulle vra. Die vraag wat skynbaar onderliggend is, is: 'Is wat ek kies of doen die moeite werd?' Relatiwiteit het die werkwoord van ons tyd geword:

Apart from aesthetics, the areas most affected by the postmodern challenge are those philosophical discourses which are concerned with the issues of truth, certainty and relativism, and those which deal with the principles of societal organization ... The tasks of legitimizing and legislating suddenly appear wide apart, once the reasons to assume the legislating power of legitimation have been progressively eroded. (Bauman 1987:140)

Relatiwiteit moet in dié konteks nie verstaan word as ongeërgdheid nie, maar as 'relatief tot'. Die veronderstelling van en verwysing na relasies word bedoel met die gebruik van die term. Die vermoede is dat ons op pad is na ' $n$ tyd wat in 'n groter mate gekenmerk gaan word deur 'verhoudinge van waarde'. Lojaliteit het nie meer 'n vanselfsprekende aanspraak nie, en 'n belofte geld toenemend net die spesifieke konteks en verhouding waarbinne dit gemaak is. Wanneer betekenis nie meer ontsluit word nie, verval die lojaliteit en beloftes wat deel van die verhouding was. Indien die relasie verval, word na nuwe verhoudinge gesoek. Stark en Bainbridge (1996) beskryf die proses duidelik in hulle werk: A theory of religion. Reëls, voorskrifte en strukture skuif af na 'n vlak van laer waarde. Dit is juis dié relatiwiteit wat ekumene moontlik maak.

Die probleemstelling: Die huidige formulering van kerkordes, spesifiek dié van die Nederduitse Gereformeerde Kerk (NG Kerk), is nie diensbaar aan geloofsgemeenskappe wat in 'n postmoderne konteks funksioneer nie.

Die navorsingsvraag: Aan watter kenmerke sal 'n kerkorde moet voldoen om diensbaar (funksioneel) te wees aan geloofsgemeenskappe in 'n postmoderne konteks?

\section{Kerkreg as wetenskap}

Dat die studie 'n volwaardige plek in die beoefening van wetenskap, en dan spesifiek, teologiese wetenskap het, is vir die navorser belangrik. Na die mening van die navorser val die studie volledig binne die definisie van kerkreg as wetenskap soos deur Koffeman (2014) geformuleer:

Church polity as a theological discipline is: the systematic analysis, evaluation and development of the sum total of established rules as legal system that governs structures and legal relations within churches, as well as their mutual relations and their relations to the respective states, from the perspective of ecclesiology. (Koffeman 2014:3)

... It aims at the critical analyses, systematic study and practical development of positive church polity (i.e. church polity as it is in force, and usually written down in, for instance, a church order, as a dynamic entity) from an ecclesiastical perspective ... Church polity as a theological discipline should first of all be seen as a critical assessment of existing church polity in the framework of systematic and inter-cultural theology. (Koffeman 2014:23)
Coertzen (1991:152) haal Voetius aan om sy mening dat kerkreg 'n wetenskap is, te fundeer. Voetius beskryf volgens Coertzen kerkreg as die 'scientia sacra regendi ecclesiam visibelem' - die heilige wetenskap vir die regering van die sigbare kerk.

Saam met Smit (1987:17) wys Coertzen (1991:156) ook daarop dat kerkreg nie 'n laboratoriumwetenskap is nie, maar, dat om diensbaar te wees, afspeel op die speelveld van kerkwees; dit wil sê, te midde van die konteks en denkraamwerke van die kerk binne 'n bepaalde tydvak. Die beoefening van kerkreg moet 'n bruikbare basis bied vir die kerklike praktyk. Daarom, meen die navorser, sou die impak van postmoderniteit die praktiese implikasies van 'n kerkorde toets, en behoort na daardie implikasies gevra te word.

Koffeman (2014:23) meen dat kerkreg, op grond van haar verbintenis met ekklesiologie, geplaas moet word binne die groter dissipline van sistematiese teologie. 'n Teologiese konsep van wat ons meen die kerk behoort te wees, behoort die basis van kerkreg te wees. Dit is egter belangrik om te onthou dat ons teologiese denkraamwerke altyd kontekstueel gekleur is. Ons ontvang die Woord en ons tradisie binne 'n bepaalde kulturele konteks. Daarom meen Koffeman dat baie geleer kan word wanneer 'n interkulturele benadering in die navorsing gebruik sou word en verwys in dié verband na Kuester. Dit ondersteun die navorser se hipotese dat postmoderniteit ' $n$ nuwe konteks gee waarbinne Woord en tradisie ontvang word en waarbinne die kerk diensbaar moet wees. Dit beteken dus dat dié ontwikkeling na nuwe kerkordes vra wat die kerk diensbaar sal maak vir haar roeping in die nuwe wêreld.

\section{Werkswyse}

Die studie volg 'n kwalitatiewe benadering. Dié werkswyse behels die soeke na relevante literatuur en die integrering van die insigte daarin vervat vir gebruik, op 'n eerste vlak, in die NG Kerk. Dit wil voorkom asof niemand nog 'n verband probeer lê het tussen die impak van postmoderniteit en die formulering van kerkordes nie. Daar is wel reeds baie geskryf in die velde van missiologie en praktiese teologie. Werke in die velde van missiologie en ekklesiologie is die inleidende leeswerk. Dombois onderskei 'n paar metodes wat dialekties met mekaar in wisselwerking behoort te wees: regsdogmaties, regshistories, regssosiologies en regsteologies (Coertzen 1991:55). Dié dialektiek is onderliggend aan die geheel van dié navorsing.

Kerkreg en ekklesiologie is wedersyds afhanklik van mekaar. Leo J. Koffeman (2009:20-21) gebruik die metafoor van 'n transformator om dié wisselwerking te illustreer. Daar is altyd 'n wisseling tussen ideaal, droom en teorie aan die een kant, en die realiteite van die praktyk, ervaring, frustrasie en sukses aan die ander kant. Koffeman (2009:10) meen verder dat die teologiese onderbou van betrokkenes 'n beduidende impak het op hulle evaluasie van en gebruik van kerkordes. Koffeman verwys na Dingemans met betrekking tot die kerkorde se rol as ekklesiologiese vormgewer en maak die volgende 
opmerking: 'Kerkordes maken keuzes - en moeten die maken - met betrekking tot fundamentele ecclesiologische vragen. Het in een bepaalde kerk vigerende kerkrecht weerspiegelt dus een theologische positie' (Koffeman 2009:12). Coertzen (1991:125) maak die afleiding dat Dingemans (1987:79-121) van mening is dat kerkorde 'n sosiologies organisatoriese noodwendigheid is.

Dit is teen dié agtergrond dat die werke van Zygmunt Bauman (Legislators and interpreters - 1987; Intimations of postmodernity 1992; Life in fragments - 1995; Liquid modernity - 2000; The individualized society - 2001; Identity - 2004; Living on borrowed time - 2010; This is not a diary - 2012) in die navorser se eie navorsing rigtinggewend was. Die navorser het om dié rede ook die godsdiensteorie van Stark en Bainbridge (1996) nagegaan. $\mathrm{Na}$ die navorser se mening skets hulle die groot ontwerpplanne van 'n argitek, en sou 'n kerkorde een van die tegniese sketse van die 'orde-kontrakteurs' wees. Koffeman (2014:23) wys ook op die noodsaaklikheid van 'n interdissiplinêre benadering. Maatskaplike wetenskappe speel 'n rol. Dit is die grondslag vir die navorser se gebruik van sosioloë se insette.

Daarby poog die navorser ook om 'n soortgelyke deduktiewe proses te volg as wat Stark en Bainbridge (1996) in hulle werk volg. Die kenmerke wat aan die einde van die studie uitkristalliseer, moet presies dit wees wat die term veronderstel, naamlik uitkristalliseer. Die skrywers verwys na Braithwaite en Nagel om die keuse van hulle metodiek te onderskryf. Dit is een van die deduktiewe teorieë se sterk punte dat die gevolgtrekkings empiries getoets kan word, en indien bevind word dat hulle nie geldig is nie, die proses in 'trurat' nagegaan kan word om die foutiewe aannames te identifiseer.

Die gekose werkswyse wil nie die pad wat kerkordes in hulle ontwikkeling gevolg het, opneem en logies verder ontwikkel nie. Dit sou 'n modernistiese werkswyse wees. Daar word egter eerder 'n werkswyse gekies, postmodernisties, waarin die konteks waarin kerkordes van diens moet wees, duidelik verreken word.

Koffeman $(2009: 13,14)$ haal Bronkhorst, Nauta en Coertzen aan om aan te dui dat kerkreg 'n proses is waarin gehoorsaam na die Bybel geluister word. Dit is belangrik om te verstaan dat om na die Bybel te luister, beteken om te hoor hoe die Bybel met postmoderne mense in hulle konteks praat. Dit is nodig vir die kerkreg om dit vir gemeentes en gelowiges moontlik te maak om voortdurend te luister. Wanneer Koffeman die klem plaas op die durende karakter van die luisterproses, waarsku hy ook dat die kerkorde nie mag eindig in 'n grootheid wat selfs groter kan word as Christus, die Hoof van die kerk nie.

Coertzen (1991:127-129), met verwysing na Nauta, dui oortuigend aan dat die Skrif nie aan ons kant en klaar kerkordes bied nie. Hoe die kerk ook al te werk gaan, die produk mag nie in stryd wees met die regsbeginsels van die Skrif nie. Deur net teksverwysings uit die Skrif te gebruik, gaan 'n kerkorde nie help om die praktiese ordereëlings te tref waartoe 'n kerkorde geroep is nie. So 'n siening sal ook tot gevolg hê dat Bybeltekste oorlaai word met betekenisse wat hulle nie het nie. Daarom, sê Coertzen, praat Wolf van duidinge.

Hierby voeg Koffeman (2009:15) ook die opmerking dat bepaalde Bybeltekste nie so belangrik is as die wesentlike vraag 'waartoe bestaat de gemeente eigenlijk?' nie. Die antwoord op dié vraag dra die primêre gewig in die formulering van kerkordes. Kerkordes moet in hulle formulering die gemeente en kerkverband in staat stel om getrou te wees aan hulle roeping met betrekking tot 'n postmoderne wêreld.

Die navorser het ook na die werk van enkele filosowe gekyk. Dit is egter belangrik om te meld dat dit nie 'n sosiologiese of filosofiese studie is nie. Die filosofie en sosiologie het bygedra tot die verstaan van die konteks waarbinne die kerk, en veral haar ordes, van betekenis moet wees.

\section{Die kerkorde van die Nederduitse Gereformeerde Kerk histories geplaas}

Coertzen (1991:214-223) meen dat die wetenskaplike motivering van die landsheer-kerkregering die impetus was virdieontwikkeling vandiegereformeerdekerkregwetenskap. Hierop het drie opeenvolgende sisteme van kerkregering in Duitsland ontwikkel: die episkopaalse, territoriale en kollegiale kerkregeringsvorms. Die bestaan van die kerk as vereniging in terme van die territoriale kerkregeringsvorm, sou die impetus tot die kollegiale kerkregeringsvorm wees. Die kollegiale kerkregeringsvorm het, vanuit die natuurreg, uiteindelik van die kerk ' $n$ blote genootskap of vereniging van eendersvoelende of eendersdenkende individue gemaak. Die kernelement van die kollegiale stelsel is dat ampte en gesag van die organisasie ontleen word.

Die kollegialisme het ook na Nederland en Suid-Afrika deurgewerk. In Nederland het dit gestalte gevind in die Algemene Reglement van 1816 en in Suid-Afrika in die kerkorde van De Mist in 1804 en die kerkwet van 1858 in die ZAR. Tot vandag toe gebeur dit dat 'n kerkorde soos dié van die NG Kerk, wat gereformeerd wil wees, dikwels in kollegialistiese sin verstaan en gehanteer word. Dit gebeur wanneer die kerk as ' $n$ blote vereniging van lede beskou word en die besluitnemingsproses as een waarin die demokratiese meerderheid deurslaggewend is. Volgens Coertzen (1991:70) het die Sinode van 1962 wel Nauta se standpunte voorgestaan, terwyl die standpunte van Bouwman en Jansen in die teologiese klasse gedoseer is. Dit het juis die kollegialistiese interpretasies van die NG Kerk se kerkorde ondersteun. 'n Duidelik onlangse voorbeeld is die wyse waarop die besluitnemingsproses met betrekking tot die opneem van die Belydenis van Belhar as 'n belydenisskrif gehanteer is. Reglement 24 en Artikel 44 van die kerkorde van die NG Kerk gee hieraan uitdrukking.

Wanneer Coertzen (1991:214-223) die ontwikkelingsgang van kerkordes in die negentiende eeu beskryf, is dit duidelik 
dat dit grondig deur die negentiende-eeuse positivisme gekleur is. Ook die ontwikkeling van die presbiteriaal sinodale stelsel onder leiding van Calvijn en Buccer is deur die positivisme gekleur. Die rigtinggewende kerkorde in dié geval is die kerkorde van Dordt.

Strauss $(2010: 7,8)$ verwys na Vorster (1960:13) en meld dat by die aanvanklike vorming of grondlegging van die NG Kerk se huidige kerkorde in 1962 doelbewus gepoog is om 'n eietydse weergawe van die Dordtse Kerkorde (DKO) daar te stel. Die NG Kerk se kerkorde van 1962 is gebaseer op die kerkorde van 1959 van die Gereformeerde Kerke in Nederland (GKN) wat as 'n eietydse aangepaste weergawe van die DKO beskou is.

\section{Hipotese}

Kerkordes kan ingrypend vereenvoudig word om so hulle betekenis vir geloofsgemeenskappe te verhoog. Voorskrifte en vereistes kan tot die minimum beperk word. Kerkordes behoort hoogstens merkers aan te dui, waarbinne verhoudinge van waarde ontwikkel word en so bydra tot die funksionele karakter van die kerkorde.

Kerkreg kan 'n eie, rigtinggewende, kreatiewe en onmisbare rol in veranderingstrategieë speel. Kerkreg kan die implikasies van verandering voorsien en in haar prosesreëls daarvoor voorsiening maak. Die gevaar is dat ons instink ons laat laer trek en ons die kerkorde dan gebruik om skanse te bou om ons ewig teen die aanslae te beskerm. Martin Buber het al sterk gewaarsku teen die ontwikkeling van, vestiging van, sentralisering en kodifisering van denominasies wat in belang van godsdiens onderneem word, as synde lewensgevaarlik vir die hart van godsdiens (Niemandt 2007:41).

Die kerkorde sal moet ruimte maak vir prototipes. Die koestering van effektiewe prototipes is waarskynlik, volgens Michael Schrage, die kosbaarste vaardigheid wat enige organisasie kan hoop om te hê (Niemandt 2007:51).

\section{'n Postmoderne wêreld}

Die navorser kies ook doelbewus die terme 'postmoderniteit' en 'postmoderne wêreld' om die negatiewe beoordeling van die tydvak, wat eie is aan die Afrikaanse gebruik van die uitgang -isme, soos in 'postmodernisme', te vermy. Die negatiewe definisie waarmee die begrip 'postmodernisme' werk, is reeds duidelik daarin dat die term aanvanklik gebruik is om die bevraagtekening van en opstand teen funksionalisme in argitektuur te tipeer:

The concept of postmodernism was coined first; introduced as a designation of the rebellion against functionalist, scientifically grounded, rational architecture, it was soon taken over and extended to assimilate the profound changes of direction visible all over the territory of Western art. It proclaimed the end of the exploration of the ultimate truth of the human world or human experience. (Bauman 1987:118)

\section{Kenmerke van postmoderniteit}

Die kenmerke word nie in enige orde van voorkeur of belangrikheid beskryf nie - so 'n ordening sou eie wees aan 'n moderne werkswyse.

\section{Die soeke na absolute waarhede word gestaak}

Bauman (1987:118) beskryf dit soos volg: 'It proclaimed the end of the exploration of the ultimate truth of the human world or human experience.' Hy voeg dan by:

The postmodern period is distinguished by abandoning the search itself, having convinced itself of its futility. Instead, it tries to reconcile itself to a life under conditions of permanent and incurable uncertainty; a life in the presence of an unlimited quantity of compromising forms of life, unable to prove their claims to be grounded in anything more solid and binding than their own historically shaped conventions. (Bauman 1987:120)

Dit word al duideliker dat die wêreld waarin ons leef nie meer net enkel waarhede as die enigste waarhede erken nie. Individue en groepe eis toenemend hulle reg op om self te besluit wat vir hulle waarheid is, en in watter mate. Die konsep van spesialiste wat oor meerdere kennis beskik, en met rasionele vaardigheid vir ander verduidelik waar die waarheid lê, is nie meer deel van die postmoderne mens se denkraamwerk en lewenswyse nie. Die aanspraak op waarheid word toenemend getemper deur die reg tot bevraagtekening. Waarheid word bepaal deur die konteks waarbinne met die beginsels gewerk word. Foucault het in dié verband die belangrikheid van gesprekvoering beklemtoon (Dreyfus \& Rabinow 1982:85).

\section{Pluraliteit is ' $n$ gegewe}

Saam met die kontekstualisering van waarhede (waarhede word in relasies gevind), volg dit noodwendig dat daar 'n toename in betekenisgewende agente gaan wees. Verskillende vorme van waarheid, verskillende vorme van gesag en verskillende strukture van verband ontstaan, om die vakuum van die verlies aan enkel waarhede te vul. Bauman beskryf dit so:

Postmodernity is marked by a view of the human world as irreducibly and irrevocably pluralistic, split into a multitude of sovereign units and sites of authority, with no horizontal or vertical order, either in actuality or in potency. To put it in a different way, the postmodern world-view entails the dissipation of objectivity. The element most conspicuously absent is a reference to the supracommunal, extraterritorial grounds of truth and meaning. Instead, the postmodern perspective reveals the world as composed of an indefinite number of meaning-generating agencies, all relatively self-sustained and autonomous, all subject to their own respective logics and armed with their own facilities of truth-validation. (Bauman 1992:35)

Pluraliteit het eintlik die bron van hoop vir 'n vasgeloopte wêreld geword. Die veelvoude van waarhede en strukture bied soveel meer geleenthede.

\section{Postmoderniteit is die vrug van moderniteit}

Moderniteit se bedoeling was volgens Bauman om alle vorme van onsekerheid te orden: 
The kind of society that, retrospectively, came to be called modern, emerged out of the discovery that human order is vulnerable, contingent and devoid of reliable foundations. That discovery was shocking. The response to the shock was a dream and an effort to make order solid, obligatory and reliably founded. This response problematized contingency as an enemy and order as a task. It devalued and demonized the 'raw' human condition. It prompted an incessant drive to eliminate the haphazard and annihilate the spontaneous. As matter of fact, it was the sought-after order that in advance construed everything for which it had no room or time as contingent and hence lacking foundation. The dream of order and the practice of ordering constitute the world. (Bauman 1992:xi)

Bauman se beskrywing van moderniteit in die volgende aanhaling spreek boekdele:

The typically modern view of the world is one of essentially orderly totality; the presence of a pattern of uneven distribution of probabilities allows a sort of explanation of the events which if correct - is simultaneously a tool of prediction and (if required resources are available) of control. Control ('mastery over nature', 'planning', or 'designing' of society) is well-nigh synonymously associated with ordering action, understood as the manipulation of probabilities (rendering some events more likely, others less likely). Effectivity of control and correctness of knowledge are tightly related (the second explains the first, the first corroborates the second)... (Bauman 1987:3)

Dit was egter juis dié onhaalbaarheid van die ideaal wat 'n reaksie van relatiwiteit, diversiteit en pluraliteit tot gevolg gehad het:

The subsequent divorce between the state and intellectual discourse, together with the inner transformations of both spheres, has led to an experience articulated today in a worldview and associated strategies often referred to under the name of 'postmodernity'. (Bauman 1987:2)

\section{Wette en reëls word vervang deur waardes}

Dit sal foutief wees om te meen dat die relatiwiteit wat kenmerkend van die postmoderne wêreld is, gelyk is aan relatiwisme. Daar word wel nie meer na enkel waarhede gesoek nie, maar na ' $n$ veelvoud van waarhede, relatief tot die konteks. Indien individue en groepe vra na die redes vir skynbaar disfunksionele waarhede, en dan ander kies, is dit omdat bepaalde waardes ter sprake is. Elke keuse word gegrond op 'n waardeoordeel wat deur die individu of groep gemaak word:

What makes a strategy which refuses to renounce its modern commitments a 'postmodern' one, is the bluntness with which its premises are recognized as assumptions; in a truly 'postmodern' vein, such a strategy refers to values rather than laws; to assumptions instead of foundations; to purposes, and not to groundings. And it is determined to do without the comfort it once derived from the belief that 'history was on its side', and that the inevitability of its ultimate success had been guaranteed beforehand by inexorable laws of nature... (Bauman 1992:108)

Hierdie proses (die skuif weg van wette na waardes) word soms sekularisasie genoem. Oor sekularisasie is daar in kerklike kringe 'n redelik negatiewe beoordeling.
Die negatiwiteit is egter nie noodwendig nodig nie. Linda Woodhead formuleer dit soos volg:

... It is still possible to hold religious beliefs even though they have ceased to be taken-for-granted certainties - but it is impossible to hold them in the same way. People continue to be religious ... but are religious in new ways - even when the new ways present themselves as a return to the old ways. (Woodhead 2001:2)

\section{Stark en Bainbridge (1996) skryf so oor sekularisasie:}

Secularization is not merely a feature of the contemporary cultural scene, but a permanent process in every religious tradition. The result, however, is not the extinction of religion, but the weakening of some particular religious organizations. The counterbalancing processes of revival and innovation keep religion, in general, alive. (p. 117)

The decline of power in low-tension churches, the ease of denominational switching, and the continuing human desire for unavailable rewards mean that one striking consequence of secularization is a flowering of religion, not its demise. Secularization produces an era of religious revival and experimentation. ('n verwysing na Bell 1971, 1980 Religion in the sixties, Social Research 38:447- 497 en The winding passage, Abt Books, Cambridge, MASS [1987:304])

Onsekerheid en ongemak is die brandstof van godsdiens!

\section{Die definisie van die konsep van vooruitgang verander: Diskontinuïteit word aanvaar as gegewe}

Moderniteit het met die oortuiging gewerk dat die mens met sy rede alle probleme kan oplos, en deur logika 'n beter toekoms kan skep. Die uitgangspunt was dat misterie verklaar kan word. Rampe en nood kan deur kreatiewe denke, die bron van die mens se gewaande skeppingsvermoë, voorkom word. Die mens en sy vermoë kan verbeter word, op 'n pad van vooruitgang, waaraan daar nie einde sou wees nie:

... the educated elite forged the idea of progress from the untarnished experience of its own superiority ... the educated elite coined the idea of the pliability of human nature, its capacity for being moulded and improved by society, out of the experience of its own role in the disciplining, training, educating, healing, punishing and reforming aimed at categories other than itself. (Bauman 1987:110)

Elke prestasie het egter ook sy skadukant gehad. Kernkrag word 'n kernbom. Maatskaplike ingenieurswese kon nie werkloosheid voorkom nie. Kennis het ' $n$ instrument geword waardeur daar ook gediskrimineer is.

\section{Bauman laat hom baie sterk hieroor uit:}

What the theory of postmodernity must discard in the first place is the assumption of an 'organismic', equilibrated social totality it purports to model in Parsons-like style: the vision of a 'principally co-ordinated' and enclosed totality (a) with a degree of cohesiveness, (b) equilibrated or marked by an overwhelming tendency to equilibration, (c) unified by an internally coherent value syndrome and a core authority able to promote and enforce it and (d) defining its elements in terms of the function they perform in that process of equilibration or the reproduction of the equilibrated state. 
The theory of postmodernity must be free of the metaphor of progress that informed all competing theories of modern society. With the totality dissipated into a series of randomly emerging, shifting and evanescent islands of order, its temporal record cannot be linearly represented. Perpetual local transformations do not add up so as to prompt in effect an increased homogeneity, rationality or organic systemness of the whole. (Bauman 1992:189)

\section{Die groter geheel definieer nie meer die waarde van sy onderdele nie}

Dit was vir baie dekades vanselfsprekend dat die individu ondergeskik aan die groep was. Die konsep van 'n superras het beide burgers en ander rasse ingebind. Kapitalisme en kommunisme het dieselfde konsep gebruik om burgers in gelid te hou. Nou het die individu, en die onderdele van die geheel hulle eie bestaansreg, waarde en sinvolheid ontdek:

\begin{abstract}
... the theory of postmodernity would do well if it disposed of concepts like system in its orthodox, organismic sense, suggestive of a sovereign totality logically prior to its parts, a totality bestowing meaning on its parts, a totality whose welfare or perpetuation all smaller units serve; in short, a totality assumed to define, and be practically capable of defining, the meanings of individual actions and agencies that compose it. A sociology geared to the conditions of postmodernity ought to replace the category of society with that of sociality; a category that tries to convey the processual modality of social reality ... (Bauman 1992:190)
\end{abstract}

\section{Die onmoontlike kry nuwe lewe}

As al die absolute waarhede dan nie so seker is nie, en al die reëls en wette nie die finale uitkomste bepaal nie, dan is daar skielik weer nuwe hoop. Ontnugtering en onsekerheid maak die deur oop vir alternatiewe. Hiermee help Derrida ons. Caputo en Scanlon (1999) som Jacques Derrida se standpunt so op:

On this telling, the new Enlightenment would constitute a second childhood which is given over to dreaming of the impossible, arising from a deep desire for what, given the constraints and conditions imposed by modernity, is precisely not possible, which for that reason is precisely what we most deeply desire.

But everything interesting for Derrida is impossible, not simply, logically or absolutely, impossible, but what he calls the impossible ... For the impossible is indeed an 'aporia' - which means 'no way to go' - but in deconstruction aporias are made to be broken, not to drive us off the road ... Being impossible is what ignites our passion ... All of which is a way of saying that deconstruction is structured like a religion. Like a prayer and tear for the coming of the wholly other (tout autre), for something impossible, like a messianic prayer in a messianic religion, viens, like a vast and sweeping amen, viens, oui, oui. Like a faith in the coming of something we cannot quite make out, a blind faith where knowledge fails and faith is what we have to go on ... Deconstruction thus turns out to be not the final nail in the coffin of the old God, but rather the affirmation of the religious, not the leveling but the repetition of the religious, and this while Derrida can 'quite rightly pass for an atheist'... (Caputo \& Scanlon 1999:3, 4)

Richard Kearney skryf in dieselfde werk van Caputo \& Scanlon: 'Deconstruction is the desire for the impossible as possible, that is, beyond all our intentional horizons of possibility' (Caputo \& Scanlon 1999:124). Die gevolgtrekking is dan dat as die reëls, voorskrifte en voorspellings nie noodwendig waar is nie, die onmoontlike nie noodwendig onmoontlik nie, die verbode nie noodwendig verbode nie, en die voorspelde en gestruktureerde uitkoms nie noodwendig die uitkoms nie, en die gevolge nie noodwendig die gevolge nie, dan kan daar alternatiewe wees, en dus hoop.

Wat verder belangrik is, is die feit dat die moontlikheid van die onmoontlike 'n onbeperkte aantal vorme kan aanneem:

The typically postmodern view of the world is, in principle, one of an unlimited number of models of order, each one generated by a relatively autonomous set of practices. Order does not precede practices and hence cannot serve as an outside measure of their validity. Each of the many models of order makes sense solely in terms of the practices which validate it. In each case, validation brings in criteria which are developed within a particular tradition; they are upheld by the habits and beliefs of a 'community of meanings' and admit of no other tests of legitimacy... (Bauman 1987:4)

\section{Kommunikasie verander die wêreld}

Hunter verwoord die implikasie van elektroniese kommunikasie absoluut helder:

These electronic media have transformed the nature of conciousness and culture as well ... these media transform time and space by radically 'compressing them', transforming the objective qualities of space and time by accelerating or eliding spatial and temporal distances.

... electronic media ... compartmentalize the world and place its parts together in incoherent ways, as when a news report on famine in Africa is followed by an advertisement offering pharmaceutical help for erectile dysfunction, which is then followed by the latest results of the NCAA basketball tournament in Charlotte, North Carolina; the stock market news from New York, London, Frankfurt, and Tokyo; a murder trial in Los Angeles; and so on.

... entertainment becomes the primary format for representing experience. Though the appeals are different, the pressures are every bit as great for the evening news as for prime-time drama, and for televised worship services as for sporting events. Here too, distinctions in content are mashed together and flattened out ... (Hunter 2010:208-209)

Die ontwrigting wat dié verwikkelinge in kommunikasie meebring, lê nie net in die spoed waarmee hulle gebeur, en die gevolglike gebrek aan tyd om gebeure en besluite deeglik te oorweeg nie. Die groter probleem is dat sake van kritieke waarde vermeng word met sake van mindere waarde, asof dit op dieselfde vlak van waarde lê.

\section{Die perspektiewe van Zygmunt Bauman se betekenis Enkele waarnemings deur ander skrywers verwoord}

Dennis Smith (1999:26-32) beskryf die invloed van ander skrywers op Bauman. Tot en met die 1980s is Bauman beïnvloed deur Karl Marx, Antonio Gramsci en Jurgen Habermas. Van Marx het hy die belangrikheid oorgeneem 
van beheer as instrument waarmee ons wêreld verstaan kan word. Van Gramsci het hy die oortuiging oorgeneem dat die krag van kapitalisme toegeskryf kan word aan die feit dat kapitalisme se beheermaatreëls en idees die hele gemeenskap geïnfiltreer het. Met Habermas deel hy die oortuiging dat kulturele wetenskappe, soos sosiologie, hermeneuties van aard is. Die verstaan van die betekenis (waardes, doelwitte, nuanses en wêreldbeskouings) wat verskillende lewensvorme soos klasse, nasies en etniese groepe onderlê, is belangrik. Dit het ook die toetssteen vir waarheid geword.

Teen die middel van die 1990s is bogenoemde drie vervang deur Michel Foucault, Theodor Adorno en Emmanuel Levinas. By Foucault het hy aansluiting gevind betreffende die konsep van dissipline. Van Adorno het hy die belangrikheid daarvan oorgeneem om jou eie ervarings van ballingskap intellektueel betekenisvol te maak. Hy het die rol van die vreemdeling gebruik om die mistastings van ideologieë wat ander troos, uit te daag. Sy vyand is die Verligting, wat 'vreemdes' en als wat 'vreemd' is, gevrees het; in navolging van Levinas is dit Bauman se uitdaging om moraliteit die 'absolute nuwe begin' te maak, om etiek voor ontologie te plaas. Die antwoord lê dan vir hom daarin dat die mens sal leer om 'vir die Ander' te wees, om verantwoordelikheid teenoor ander te hê, selfs voordat jy self bestaan.

Keith Tester (Bauman \& Tester 2001:12): 'Bauman argues ... that morality is about commitment to the other over time.' Benedetto Vecchi (Bauman \& Vecchi 2004:3): 'We have here an intellectual who considers the principle of responsibility to be the first act of any involvement in public life.

\section{Bauman se verstaan van postmoderniteit}

Bauman beklemtoon dat die postmoderne wêreld totaal anders, soms teenstrydig anders, as die wêreld van moderniteit funksioneer. Dit het alles te doen met die manier waarop ons onsself beleef en verstaan. Dit het ten diepste te doen met identiteit. Kerklik gesproke het dit te doen met die manier waarop die kerk haar roeping verstaan en haar identiteit definieer. Volgens Bauman, wil dit voorkom of die soeke na identiteit in die postmoderne wêreld belangriker geword het as die soeke na waarheid:

The postmodernist debate is about the self-conciousness of Western society, and the grounds (or the absence of grounds) for such conciousness. The concept of postmodernism ... proclaimed the end of the exploration of the ultimate truth of the human world or human experience. (Bauman 1987:118)

The postmodern period is distinguished by abandoning the search itself, having convinced itself of its futility. Instead, it tries to reconcile itself to a life under conditions of permanent and incurable uncertainty; a life in the presence of an unlimited quantity of compromising forms of life, unable to prove their claims to be grounded in anything more solid and binding than their own historically shaped conventions. (Bauman 1987:120)

Identiteit het nie meer te doen met sekerhede uit die verlede nie, maar met die onsekerhede van nou en die toekoms.
Ons identiteit word nie meer gedefinieer deur ooreenkomste nie, maar deur verskille, en die manier waarop betekenisvol geleef word in verhoudinge waar die verskille omarm word.

'n Volgende kernelement is die belangrikheid van diversiteit. Dit daag die modernistiese klem op uniformiteit uit. Verskillende vorms van lewe en uitdrukking het legitimiteit. Elkeen IS, en MAG daarom ook. Elke lewensvorm bestaan en het bestaansreg - dit is. Die verskillende lewensvorme is ook nie afwykings, onvanpas, barbaars of onbehoorlik nie. Die terme gepeupel ('people'), onbeskaaf, gekultiveerd, barbaars, opgevoed, onbeskof, is terme eie aan moderniteit:

Postmodernity is marked by a view of the human world as irreducibly and irrevocably pluralistic, split into a multitude of sovereign units and sites of authority, with no horizontal or vertical order, either in actuality or in potency. To put it in a different way, the postmodern world-view entails the dissipation of objectivity. The element most conspicuously absent is a reference to the supracommunal, extraterritorial grounds of truth and meaning. Instead, the postmodern perspective reveals the world as composed of an indefinite number of meaning-generating agencies, all relatively selfsustained and autonomous, all subject to their own respective logics and armed with their own facilities of truth-validation. (Bauman 1992:35)

Beilharz wys op Bauman se standpunt dat die konsep van pluraliteit dié beskerming teen barbaarsheid is:

Pluralism is the best preventative medicine against morally normal people engaging in morally abnormal actions. The voice of individual moral conscience is best heard in the tumult of political and social discord ... For Bauman insists that if there is one central theme following from the Milgrim experiments, it is that cruelty correlates with certain patterns of social interaction much more than it does with personality features or other individual idiosyncracies of the perpetrators: 'Cruelty is social in its origin much more than it is characterological'. (Beilharz 2000:100)

Die konsep van relatiwiteit is nou aan bogenoemde verbonde. Hiermee bedoel die navorser nie relatiewe ongeërgdheid nie, maar om 'in verhouding tot' die onseker diversiteit te staan. Alles en almal staan relatief tot mekaar. Dit is nie 'n verhouding wat vasgevang is in ' $n$ vaste, voorgeskrewe sisteem nie, maar een wat vloeibaar met die getye van konteks, tradisie en betekenis tussen hoog- en laagwater wissel. Relasies verdiep en vervlak, vorm, ontbind, stagneer, herleef. Identiteit en betekenis word in terme van verhoudinge gedefinieer, in terme van 'behoort aan' en 'is deel van'. Postmoderniteit is dus iets wat baie ernstig opgeneem moet word - dit is nie net ' $n$ verbygaande modegier nie:

I suggest, in other words, that the phenomena described collectively as 'postmodernity' are not symptoms of systemic deficiency or disease; neither are they a temporary aberration with a life-span limited by the time required to rebuild the structures of cultural authority. I suggest instead that postmodernity ... is an aspect of a fully-fledged, viable social system which has come to replace the 'classical' modern, capitalist society and thus needs to be theorized according to its own logic. (Bauman 1992:52) 


\section{Van wildbewaarder tot tuinier (wetgewer), en toe van wetgewer tot vertaler}

Bauman gebruik twee metafore om die verandering in ons wêreld te illustreer. Guibentif (2007:178) meen dat Bauman juis metafore gebruik om die data en interpretasies van spesialiste, wat vir leke moeilik verstaanbaar is, duideliker te maak. Hy hoop om die verband tussen sosiologiese refleksie en openbare debat so te stimuleer. Bauman beskryf die voormoderne wêreld as die wêreld wat gekenmerk is deur natuurlike wyses van bestaan - soos in 'n wildernisgebied. Daar is bestaande konvensies en ' $n$ vorm van balans wat self in stand bly. Die konvensies en oorlewingsmeganismes is deur tradisies (ou vroue, spreuke en wysheidsfigure) oorgedra:

'Wild cultures,' says Ernest Gellner, reproduce themselves from generation to generation without conscious design, supervision, surveillance or special nutrition. 'Cultivated' or 'garden' cultures, on the contrary, can only be sustained by literary and specialized personnel. To reproduce, they need design and supervision, without them, garden cultures would be overwhelmed by wilderness. There is a sense of precarious artificiality in every garden; it needs the constant attention of the gardener, as a moment of neglect or mere absent-mindedness would return it to the state from which it had emerged (and which it had to destroy, evict or put under control to emerge). However well established, the garden design can never be relied upon to reproduce itself, and never can it be relied upon to reproduce itself by its own resources. The weeds - the uninvited, unplanned, self-controlled plants - are there to underline the fragility of the imposed order; they alert the gardener to the never ending demand for supervision and surveillance.

The emergence of modernity was such a process of transformation of wild cultures into garden cultures. Or, rather, a process in the course of which the construction of garden cultures re-evaluated the past, and those areas that stretched behind the newly erected fences, and the obstacles encountered by the gardener inside his own cultivated plot, became the 'wilderness'. (Bauman 1987:51)

Vyf jaar later sou Bauman homself nog selfs sterker uitlaat oor die 'kultuurideaal' van moderniteit:

The intellectual ideology of culture was launched as a militant, uncompromising and self-confident manifesto of universally binding principles of social organization and individual conduct. It expressed not only the exuberant administrative vigor of the time, but also a resounding certainty as to the direction of anticipated social change. Indeed, forms of life conceived as obstacles to change and thus condemned to destruction had been relativized; the form of life that was called to replace them was seen, however, as universal, inscribed in the essence and the destination of the human species as a whole. (Bauman 1992:11)

Die vraag is dan of die noodsaaklikheid aan 'n kerkorde nie dalk ' $n$ aanduiding is van die kunsmatigheid van die huidige sisteem nie, eerder as 'n aanduiding van die inherente boosheid daarvan. Het ons die reëls nodig omdat gelowiges en gemeentes inherent boos is, of omdat ons probeer om 'n kunsmatige sisteem in stand te hou?
Die debat oor kerkmusiek is sprekend:

The eviction of popular orchestras from churches and their replacement with hired organists was another episode in the same cultural crusade ... Vic Gammon's research leaves little doubt ... The Church-sponsored press did not mince words in alerting enlightened parishioners ... The Parish Choir, 1846-51 ... 'Nothing can be more certainly fatal to the good cause, than placing the management of the music in crude and vulgar hands.' The Church of England Quarterly Review noted with satisfaction that 'the days are happily numbered in which a fiddle and a bassoon were looked upon as the appropriate accompaniments to a church choir'... (Bauman 1987:66)

Die probleem was nie die instrumente nie, maar die beoordeling en klassifisering van mense as van minder of meerdere waarde.

Tydens die Verligting, sê Bauman, is die wildernis omvorm tot 'n tuin. Met die klem op die mens se vermoë om met sy rede en absolute waarhede sy wêreld te vervorm tot die utopie wat hy bedink het, het die mens begin tuin maak. Die uitgangspunte was die sistematiese ordening, uniformiteit, voorspelbaarheid en absolute waarheid, waarmee alle gebeure bestuur is, gras gesny, akkers gevorm, onkruid verwyder en beter genetiese materiaal geskep is (cultivated/kultuur!) In die proses is alle vorme van lewe wat nie in die program pas nie, uitgewis, of hervorm indien moontlik. Die 'gepeupel' is verklaar tot die arbeidsveld van dié wat beter weet. Alle vorme wat eie was aan die wildtuin is uit die sisteem geweer.

Smith (1999:119) wys daarop dat ons in reaksie op postmoderniteit dalk kan meen dat ons weer gemeenskappe kan skep wat vooraf goedgekeurde waardesisteme sal nastreef. Saam met Bauman meen hy dat gemeenskappe nie doelbewus 'gefabriseer' kan word nie. Gemeenskappe gebeur eenvoudig:

As Robert Pawlik perceptively and clearly expressed it [in Kronos 2(2010), bl.44], 'Ecclesia is formed through messianic suspension of all extant dividing lines. A messianic event is a breakthrough and upturn so radical that it results in 'de-activation' of legal orders heretofore in operation - religious as much as political... From this moment on (in the 'messianic era'), human relationship is no longer regulated by law and by associated hierarchies and power relations, but by love of one's neighbour. (Bauman 2012:74)

Wanneer lede van gemeenskappe selfbewus raak oor hulle bronne van mag, is dit 'n seker teken van hulle agteruitgang. Gemaakte gemeenskappe dwing graag hulle reëls op randfigure en agterosse af. 'When the visible church is primarily concerned with its image, its growth, its success, and its security, then it is ripe for conversion...' (Guder 1998:229). Dit verklaar dalk die drang in die NG Kerk-familie om hulle eie oortuigings met betrekking tot, onder meer, die Belydenis van Belhar en kerkeenheid, op ander af te forseer by wyse van kerkordelike prosesse. Dié wat anders van oortuiging is, word tot ketters verklaar.

'The typically modern strategy of intellectual work is one best characterized by the metaphor of the "legislator" role' (Bauman 1987:4): 
To summarize, the structures of modernity express the interests of a legislating elite of bureaucrats and intellectuals, which has employed its 'gardening' skills to 'cultivate' a population that behaves as if it is under constant surveillance ... Modernity also expresses the human desire to impose order and meaning upon nature and society, to conquer all potential sources of uncertainty and to achieve security even at the cost of freedom. (Smith 1999:141)

Daar is 'n toenemende soeke na die natuurlike wat verloor is. In postmoderniteit vind die soeke uiting in die privatisering en individualisering van lewensvorme. Mense soek na hulle eie tradisie, waarheid en antwoord op die gebrokenheid. Daar word gesoek na gemeenskap - maar op eie terme. Wat nou nodig is, is nie meer tuiniers en wetgewers nie, maar vertalers wat individue en individuele groepe se verhale outentiek kan vertaal en interpreteer sodat hulle deur ander gehoor en gerespekteer kan word. Dit is die tweede metafoor wat Bauman gebruik:

The typically postmodern strategy of intellectual work is one best characterized by the metaphor of the 'interpreter' role. It consists of translating statements, made within one communally based tradition, so that they can be understood within the system of knowledge, based on another tradition. Instead of being orientated towards selecting the best social order, the strategy is aimed at facilitating communication between autonomous (sovereign) participants. It is concerned with preventing the distortion of meaning in the process of communication. (Bauman 1987:15)

The interpreter approaches what is familiar to the author as though it is foreign or unknown ... It seeks out resonances and dissonances between inside and outside, older and more recent. The interpreter is therefore a messenger, only the message is not self-evident; for contemporary hermeneutics the interpreter is the receiver, and not only the agent of transmission. (Beilharz 2000:67)

In contrast, again, and though Bauman does not summon up this precise word here, the typically postmodern strategy of intellectual work is hermeneutic. The postmodern intellectual is a translator, not an arbiter. He or she translates statements, made within one communally based tradition, so that they can be understood within the system of knowledge based on another tradition. Interpreters do not decide on behalf of others; they seek rather, to facilitate communication between different autonomous participants. (Beilharz 2000:76)

Smith (1999:26) meen dat Bauman in die 1990s weggedraai het van bloudrukke en metodologieë. Bauman het self 'n vertaler geword, 'n sensitiewe buitestander wat gesoek het na betekenisse wat nog vir ander verskuil kon gewees het. Bauman verwys na Gadamer se Truth and method, om die noodsaaklikheid vir die rol van die 'interpreter' te staaf Bauman (1987:144):

The idea of interpretation assumes the meaning-constituting authority to reside elsewhere - in the author, or in the text; the role of the interpreter boils down to reading out the meaning. The good interpreter is one who reads the meaning properly and there is a need (or so one may hope) for someone to vouch for the rules which guided the reading of the meaning and thus made the interpretation valid or authoritative; somebody who would sieve good interpretations from bad ones. But the strategy of interpretation does differ from all strategies of legislation in one fundamental way: it does abandon overtly, or put aside as irrelevant to the task at hand, the assumption of the universality of truth, judgement or taste; it refuses to differentiate between communities which produce meanings; it accepts those communities' ownership rights, and the ownership rights as the only foundation the communally grounded meanings may need. (Bauman 1987:197)

As daar dan reëls moet wees, dan hoogstens reëls wat ruimte skep vir verhoudinge van betekenis. Bauman verwys ook na Derrida en wys op die belangrikheid daarvan om te verstaan dat die interpretasie ook nooit afgehandel is nie, maar vir altyd sal aanhou. Dit is die rede vir die belangrikheid van verhoudinge waarbinne die interpretasie kan voortgaan:

The central message of Derrida is that interpretation is but an extension of the text, that it 'grows into' the text from which it wants to set itself apart, and thus the text expands while being interpreted which precludes the possibility of the text ever being exhausted in interpretation. Derrida's philosophy of deconstruction asserts the inescapability of multiple meaning and the endlessness of the interpretive process. (Bauman 1992:132)

\section{Oor outoriteit, mag, gesag en wette}

Hoekom het wette 'n wesentlike deel van die samelewing geword? Die tuin moes gekultiveer word! Die oorspronklike ontwerp, die wildernis, moes herontwerp word. 'n Nuwe tuin is aan die hand van die menslike rede uitgelê. Al die agente van wysheid uit die ou wêreld is nietig verklaar. Die nuwe tuinwerkers (fabriekswerkers en soldate), moes die regte handelinge uitvoer. Almal moes die meesterplan ken en nakom. Almal moes hulle rolle na die letter van die ontwerp uitvoer. Niemand kon dit egter uit hulleself doen nie en kon ook nie daarmee vertrou word nie. Die burgers of gepeupel was onkundig, volgens die oordeel van die meesters van die rede. Daarom is wette gemaak. Beilharz (2000:78) wys daarop dat die drang om reëls te formuleer sy oorsprong het in die moderniteit wat van 'wildbewaarders' 'tuiniers' gemaak het. Die spesialiste het gemeen om die redders van die 'ongewastes' te wees.

Die hele sisteem was daarop gerig om gehoorsaamheid te kweek. Gehoorsaamheid was die deug, selfs al sou individualiteit en diversiteit opgeoffer moes word. Teen elke prys moes die burger geleer word om in gelid te leef.

Wanneer Beilharz $(2000: 96,99)$ in dié verband na Bauman verwys, dui hy die donker kant van wette duidelik aan. Hy wys daarop hoe moderniteit vir ons die instrumente gegee het wat dit vir ons moontlik gemaak het om minder humanitêr te handel. Hy dui aan hoe fascisme nie die resultaat van chaos of kranksinnigheid is nie, maar uitgevoer word deur foutlose, noukeurige wet en orde. Hy wys op die gemoderniseerde afstand wat deur effektiewe organisasie geskep word, en wat dit vir die agent moontlik maak om lyding te veroorsaak, en nog steeds vrede in homself te hê. Dit is gemeganiseerde afstand en anonimiteit wat die moontlikheid open van wreedheid teenoor ander wat nooit deur iemand benadeel sou word as hy die ander in die oë sou kyk nie. 
Volgens Bauman (1995:34) het moderniteit gemeen dat reëls tussen orde en chaos staan, tussen humaniteit en dierlikheid, tussen bewoonbaar en onbewoonbaar, tussen betekenis en sinloosheid. Wette was nodig vir elkeen en vir alles wat gedoen kan word. Etiek was 'n noodwendige deel van die gejaag na wette. Mense moes gedwing word om hulle plig na te kom, en geleer word dat dit goed is. Die gedrag kon ook net verseker word deur toegepaste wette. Moderniteit het die eeu van etiek geword:

There is a hole in the heart of modernity. It is called ethics. Moderns fill this hole with order, with rules and regulations. Ethics was a chance given to moderns, who have been unable largely to take on the challenge, for they are still traditionalists at heart, creatures of habit, for whom the prospect of autonomy is simply too much; easier to just follow the rules. By this process morality or conventionalism is substituted for ethics, or care of the self and others; and in turn moralism or hectoring replaces morality, or else morality gives way to law: we let the magistrates and black letter law books tell us how to live ... The legislators, in short, expected the worst of the masses, presuming that their natural intelligence would always play into vice or self-interest. (Beilharz 2000:123)

\section{Oor relatiwiteit}

Daar kan gevra word na die posisie van indringerplante. Bauman sou die metafoor afwys. Elke indringerplant het sy bedoelde plek gehad, voordat die tuiniers van die wildernisgebied 'n afgebakende blomtuin gemaak het. Die metafoor wil juis aan die indringer weer sy regmatige plek toeken. Daarby sou 'n metafoor waarin die indringer as sonde of vyand beskou word, ook nie geldig wees nie. Die Evangelie handel met sonde tog heel anders, by wyse van 'n plaasvervangende offer, vergifnis en versoening, wat alles intense verhoudinge van betekenis veronderstel. Diegene wat anders dink en doen as ek of ons is nie vyande of opponente nie. Indringerplante speel volgens Bauman eerder 'n profetiese rol, wat die kunsmatigheid van bestaande sisteme uitwys. Daarby sou ek werklik kan oordeel oor die motiewe van ander se geloof en geloofshandeling, sonder om hul stories in 'n opregte verhouding, met die hulp van 'n vertaler, te ontdek. Derrida se antwoord, volgens Kearney, op die argument is dat reëls noodgedwonge geskep moet word om die gevaar van die monster te bestuur:

What I mean is that when we control a border, when we try to discriminate, when we try to find criteria to discriminate between the enemy and the friend, or between the monster and the god, then the indispensable act of knowing, discriminating, adjusting the politics, is indispensable, no doubt, but it is a way of limiting hospitality. We have to be aware that, to the extent that we are looking for criteria, for conditions, for passports, borders and so on, we are limiting hospitality, hospitality as such, if there is such a thing. I'm not sure there is pure hospitality. But if we want to understand what hospitality means, we have to think of unconditional hospitality, that is, openness to whomever, to any newcomer ... So I need what Kant would call the regulating idea of pure hospitality, if only to control the distance between inhospitality, less hospitality, and more hospitality. This could also lead us beyond Kant's own concept of hospitality as a regulating idea. (Caputo \& Scanlon 1999:132-133)

\section{Gevolgtrekkings}

Kerkordes sal aan die volgende kenmerke gemeet word:

- Hulle voeg betekenis toe tot verhoudinge.

- Hulle erken die geldigheid van die konsepte: relatiwiteit en inkulturasie.

- Hulle laat ruimte vir kontekstuele luisterprosesse ten einde die vertalingsproses te fasiliteer en geregtigheid te laat geskied deur te luister.

- Hulle skep ruimte vir eksperimentering en diversiteit.

- Hulle laat die komplementêre aard van kerkwees ontkiem, en respekteer die ontwikkeling van 'n ruimer ampsbeskouing.

Die vraag aan enige formulering van 'n kerkorde sal dus wees: Hoekom die reël, en hoekom die formulering?

In die konteks van die NG Kerk waar onder meer geworstel word oor die plek van die Belydenis van Belhar, kerkeenheid met die VGKSA, NGKA en DRC, en met die verstaan van homoseksualiteit, sal met die impak van postmoderniteit rekening gehou moet word. Die prosesse gaan nie deur sinodale besluite, ooreenkomste op nasionale vlak en kerkordelike wysigings bestuur word nie. Die instinktiewe reaksie van gemeentes teen so 'n bestuursproses sal weerstand bied.

Die ontwikkeling van en ruimte vir prototipes en eksperimentering, met verhoudinge van betekenis tussen gemeentes is die aangewese weg. Al wat sinodes kan doen, is om gemeentes toe te laat om meer vorme van verband te ondersoek en te vestig sonder voorskrif of benadeling van regte. 'n Ander of 'tussen'-kerkorde wat deur almal aanvaar word, gaan nie diensbaar wees nie. Gee net aan gemeentes die ruimte om na innerlike oortuiging, op grond van hulle eie belydenisgrondslag en identiteitsvorming, te assosieer met gemeentes van soortgelyke oortuiging (byvoorbeeld met betrekking tot kerkeenheid). Die gemeentes sal dan uit oortuiging voor loop, as voorbeelde van verhoudinge van betekenis, en ' $n$ nuwe of ' $n$ herstelde kerkverband sal op grond van die verhoudinge van betekenis ontkiem en groei. Prototipes sal die saad wees wat langs die waterstrome van verhoudinge ontkiem en groei tot bome wat vrugte dra.

\section{Erkennings Mededingende belange}

Die outeurs verklaar hiermee dat hulle geen finansiële of persoonlike verbintenis het met enige party wat hulle voordelig of nadelig kon beïnloed het in die skryf van hierdie artikel nie.

\section{Outeursbydrae}

D.H.D. het navorsing gedoen oor die implikasie van postmoderniteit vir die formulering en implimentering van kerkordes. Die navorsing is gedoen vanuit die ervaring van 'n leraar in die Ned.Geref.Kerk ter verwerwing van die graad D.Div. aan die Universiteit van Pretoria. J.M.v.d.M. is 
professor in die Departement Kerkgeskiedenis van die Teologiese Fakulteit van die Universiteit van Pretoria. Hy het opgetree as promotor vir genoemde navorsing.

\section{Literatuurverwysings}

Bauman Zygmunt, 1987, Legislators and interpreters, Polity Press, Cambridge, U.K. Bauman Zygmunt, 1992, Intimations of postmodernity, Routledge, London. Bauman Zygmunt, 1995, Life in fragments, Blackwell Publishers, Oxford. Bauman Zygmunt, 2000, Liquid modernity, Polity Press, Cambridge, U.K. Bauman Zygmunt, 2001, The individualized society, Polity Press, Cambridge, U.K.

Bauman Zygmunt, 2007, 'Uncertainty and other liquid-modern fears', in Přibáň Jiři (ed.) Liquid society and its law, Ashgate Publishing Ltd., Hampshire.

Bauman Zygmunt, 2012, This is not a diary, Polity Press, Cambridge, U.K.

Bauman Zygmunt \& Citlali Rovirosa-Madrazo, 2010, Living on borrowed time, Polity Press, Cambridge, UK.

Bauman Zygmunt \& Keith Tester, 2001, Conversations with Zygmunt Bauman, Polity Press, Cambridge, U.K.

Bauman Zygmunt \& Benedetto Vecchi, 2004, Identity, Polity Press, Cambridge, U.K.

Beilharz Peter, 2000, Zygmunt Bauman, Dialectic of modernity, SAGE Publications Ltd., London.

Caputo, John D. \& Scanlon, Michael J., 1999, God, the gift and postmodernism, Indiana University Press, Bloomington.

Coertzen, P., 1991, Gepas en ordelik, RGN-Uitgewers, Pretoria.

Coertzen, P., 2004, Decently and in order. A theological reflection on the order for, and order in, the church, Canon Law Monograph Series 4, Leeuwen.
Dingemans, G.D.J., 1987, Een huis om in te wonen ... Schetsen en bouwstenen voor een kerk en kerkorde van de toekomst, Boekencentrum, 's-Gravenhage.

Dreyfus, H.L. \& Rabinow, P., 1982, Michel Foucault, The Harvester Press Ltd., Sussex.

Guder Darrell, L. (ed.), 1998, Missional church. A vision for the sending of the church in North America, Eerdmans, Grand Rapids, COL.

Guibentif, Pierre, 2007, 'The liquidity and solidity of contemporary social reality: The example of social inclusion policies', in Přibán Jiří (ed.), Liquid society and its law, Ashgate Publishing Ltd., Hampshire.

Hunter, James Davison, 2010, To change the world. The irony, tragedy and possibility of Christianity in the late modern world, Oxford University Press, New York. https://doi.org/10.1093/acprof:oso/9780199730803.001.0001

Koffeman, Leo J., 2009, Het goed recht van de kerk, Uitgeverij Kok-Kampen, Kampen.

Koffeman, Leo J., 2014, In order to serve: An ecumenical introduction to church polity, Lit Verlag, Berlin.

Niemandt, N., 2007, Nuwe drome vir nuwe werklikhede: Geloofsgemeenskappe in pas met 'n postmoderne wêreld, Lux Verbi BM., Wellington.

Smit, C.J., 1984, God se orde vir sy kerk, NG Kerkboekhandel Transvaal, Pretoria.

Smit, C.J., 1987, 'Kerkreg en kerkorde in diens van kerkregering. Oorsig oor 'n beskouing', In die Skriflig, Jaargang 21, nr. 82.

Smith, Dennis, 1999, Zygmunt Bauman, prophet of postmodernity, Polity Press, Cambridge.

Stark Rodney \& William Sims Bainbridge, 1996, A theory of religion, Rutgers University Press, New Brunswick, New Jersey.

Strauss, P.J. (red.), Byderwets en gereformeerd, Pro Christo, Bloemfontein.

Strauss P.J., 2010, Kerk en orde vandag: Met die klem op die NG Kerk, Sun Media, Bloemfontein. https://doi.org/10.18820/9781920383213

Woodhead, L. (ed.), 2001, Peter Berger and the study of religion, Routledge, London. 